\title{
UTILIZATION OF THE EXHAUST GAS OF A GAS PIPELINE COMPRESSION STATION TO GENERATE ELECTRICITY
}

\author{
Ehsan Amirabedin \\ M. Zeki Yilmazoglu \\ Ali Durmaz
}

Gazi University, Ankara, Turkey

\begin{abstract}
In this study, an application of an Organic Rankine Cycle (ORC) in a natural gas compression station in Erzincan region is presented. Natural gas compression station (NGCS) uses a gas turbine to pressurize the natural gas for transportation. Waste heat of gas turbine can be utilized by an ORC which uses n-pentane as working fluid to generate electricity. A costs/advantages analysis of the implementation is performed. According to designing factors, the pressure of the natural gas at the inlet and outlet of the NGCS are 48 bar and 73 bar respectively. Mass flow rate and temperature of the exhaust gas from the GT are $26.65 \mathrm{~kg} / \mathrm{s}$ and $460^{\circ} \mathrm{C}$ respectively and it shows that a significant amount of heat is rejected to the ambient. By applying an ORC to the NGCS, the results show that; total gross power via organic turbine, annual energy savings and annual cost savings are 1,385 $\mathrm{kW}, 11,057,535$ $\mathrm{kWhr}$ and 1,327,000 $\$$ respectively. Furthermore the payback time is calculated 3.77 years. Generally in this study, by utilizing an ORC in a NGCS, it has been tried to reduce the transportation cost and environmental impact of $\mathrm{NG}$ transportation.
\end{abstract}

\section{Keywords}

Natural gas transportation, Natural gas pressurization station, Organic Rankine Cycle, Waste heat.

\section{INTRODUCTION}

For the past few years, Turkey has taken a significant role in natural gas (NG) pipeline transportation. Some transportation routes such as Nabucco and Trans-Caspian are already offering the NG of the countries with rich gas reserves, to the European countries. In addition, there are some other international projects, still in the planning stage, considering Turkey as the main transport route.

In an NG pipeline the pressure of the gas drops due to friction so the gas must be constantly compressed in compression stations to provide the necessary pressure for transportation. The compression processes require large amounts of energy that are typically supplied by compressors with shaft works produced by gas turbines (GT). This production is made using a very small part of the transported NG as fuel. However, a simple analysis of the energy balance for the compression station indicates that almost $60 \%$ of the total supplied energy to a gas turbine is emitted as heat to the atmosphere mainly by hot combustion gases. This kind of waste heat is let into the environment directly; it would not only waste heat but also make

https://doi.org/10.15626/Eco-Tech.2010.061 
heat pollution to the environment [1]. The waste heat from GTs can be still useful for other purposes such as electricity generation. However, since the mass flow rate of the exhaust gas is quite low, it cannot be utilized as the heat source of a conventional Rankine cycle that operates with steam. On the other hand, an Organic Rankine Cycle (ORC) has the capability of working with such a low flow rate. Moreover, the use of an ORC in a natural gas compression station (NGCS) provides the possibility of the development of a process for improving the energy efficiency of its compression process, so the compression station can be self-sufficient in electricity consumption.

An ORC involves components similar to those used in a conventional steam power plant. However, in an ORC, the working fluid is an organic material characterized by a lower boiling point temperature than water, which, in turn, allows lower evaporating and superheating temperatures.

Kurz and Ohanian [2] indicated the parameters, which affect the performance of the compression stations. Schuster et al. [3] examined the energetic and economic of the state of the art of ORC applications. Dai et al. [4] studied an ORC comparatively and fulfilled a parametric optimization by using different working fluids in order to find optimum performance of cycles. Wei et al. [1] analyzed the thermodynamic performance of an ORC system under disturbances. Hung [5] investigated working fluids for organic Rankine cycle to recover waste heat, including benzene, toluene, p-xylene, R113 and R123. The results show that, $\mathrm{p}$-xylene shows the highest efficiency while benzene shows the lowest and p-xylene has the lowest irreversibility in recovering a high temperature waste heat while R113 and R123 have a better performance in recovering a low temperature waste heat.

In this study, using operational data taken from Erzincan natural gas compression station, located in the east of Turkey. The compression station is modified in order to use waste heat of the exhaust gas. In the modification an Organic Rankine Cycle unit is coupled to compression station and the total produced electricity is calculated during a year considering the changes of the ambient temperature. Moreover, it is tried to investigate the feasibility of the project from an economic aspect by applying the simple pay back method and net present value methods.

\section{DESCRIPTION OF THE COMPRESSION STATION}

A schematic diagram of the compression station is shown in Figure 1, Siemens SGT-200-1S model gas turbine with a total of $6250 \mathrm{~kW}$ mechanical shaft power is considered for the simulations which are performed by THERMOFLEX software [6]. Ambient air enters the cycle with a temperature of $15^{\circ} \mathrm{C}$ and then it is compressed with a pressure ratio of 12.11 in the compressor. Compressed air then enters to the combustion chamber where combustion takes place and a small proportion of the natural gas is used as fuel source with a mass flow rate of $0.382 \mathrm{~kg} / \mathrm{s}$. It is noted that, the mass flow rate of the natural gas entering the combustion chamber can be varied in different weather conditions. General properties and the composition of the natural gas are given in Table 1. Combustion gases leave the gas turbine at $476^{\circ} \mathrm{C}$ and enter the heat exchanger. On the other hand, the gas compressor is connected via a drive shaft to the three other compressors that provide the required pressure of the natural gas for pipeline transportation. There are also two intercoolers between the compressors in order to reduce the power consumption. In brief, system consists of a gas turbine and three serial compressors on the same drive shaft and two intercoolers. 


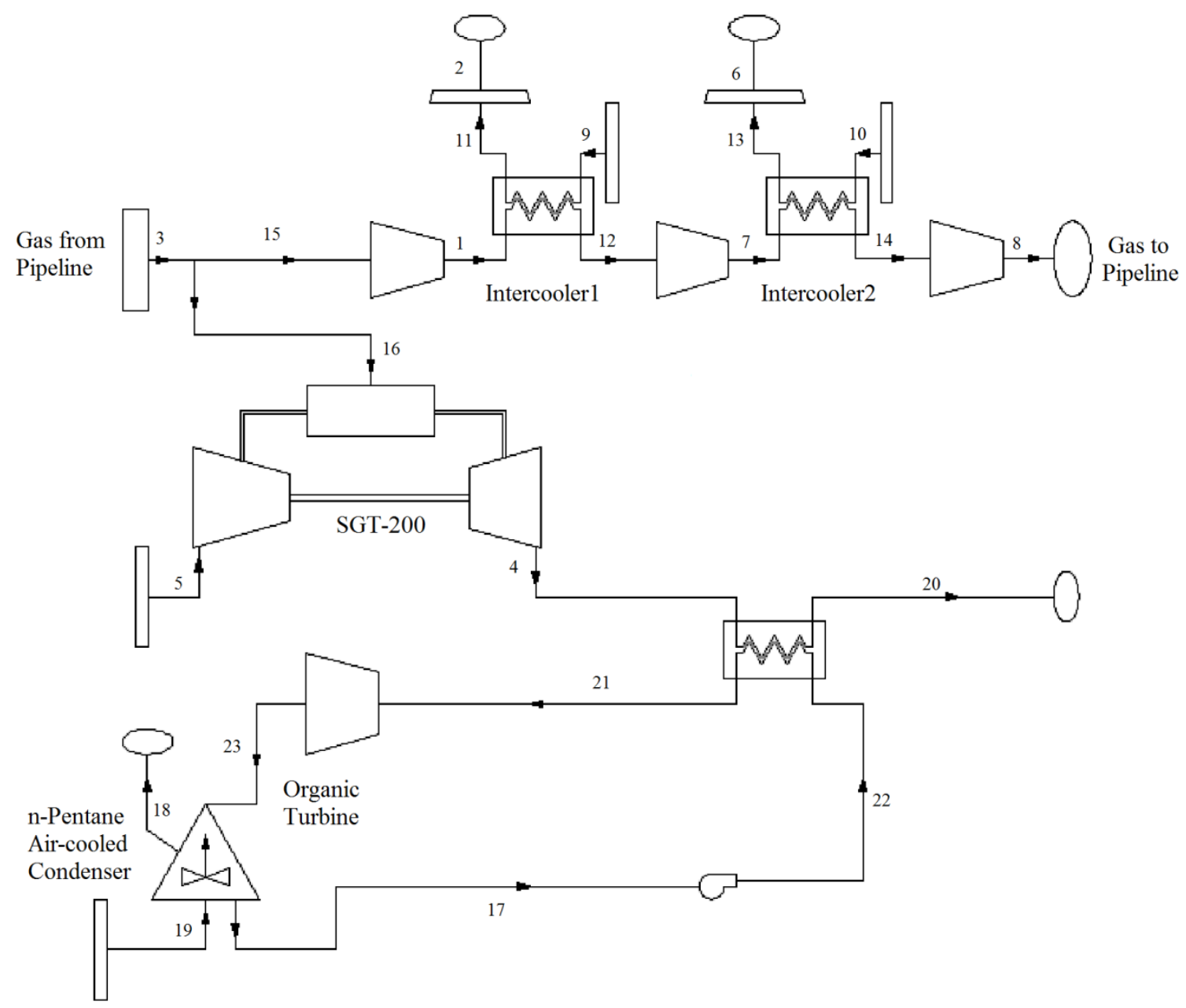

Figure 1.Schematic diagram of the modified compression station

Table 1. The composition and general properties of the natural gas

\begin{tabular}{|c|c|}
\hline NG Composition & Volume percentage [\%] \\
\hline Hydrogen, $\mathrm{H}_{2}$ & 0.36 \\
\hline Oxygen, $\mathrm{O}_{2}$ & 0.07 \\
\hline Nitrogen, $\mathrm{N}_{2}$ & 3.65 \\
\hline Carbon Monoxide, $\mathrm{CO}$ & 0.09 \\
\hline Carbon Dioxide, $\mathrm{CO}_{2}$ & 0.34 \\
\hline Methane, $\mathrm{CH}_{4}$ & 87.00 \\
\hline Ethane, $\mathrm{C}_{2} \mathrm{H}_{6}$ & 8.46 \\
\hline Ethylene, $\mathrm{C}_{2} \mathrm{H}_{4}$ & 0.03 \\
\hline Property & Value \\
\hline Average temperature in pipeline $\left[{ }^{\circ} \mathrm{C}\right]$ & 7.7 \\
\hline Inlet pressure [bar] & 48 \\
\hline Outlet pressure [bar] & 73 \\
\hline Mass flow rate $[\mathrm{kg} / \mathrm{s}]$ & 90.72 \\
\hline Lower Heating Value $[\mathrm{kJ} / \mathrm{kg}]$ & 46280.2 \\
\hline
\end{tabular}




\section{ORGANIC RANKINE CYCLE}

ORC power plant consists of an heat exchanger, single stage turbine, air-cooled condenser and a pump. The pump supplies the working fluid, which is selected as n-Pentane in this study, to the evaporator, where the working fluid is evaporated and superheated by the heat of the exhaust gas. The T-Q (Temperature-Heat) diagram of the heat recovery process is given in Figure 2. Superheated n-Pentane flows into the turbine to generate electricity and then becomes fluid in the condenser. The working fluid is then pumped to the heat exchanger and a new cycle begins. The ORC process can work with saturated vapor or a superheated organic fluid. Higher superheating in order to avoid liquid in the exhaust vapor is not necessary, because the expansion ends for most of the fluids in the area of superheated vapor in contrast to water [7]. The operation of the ORC is automatic in normal circumstances, without the need for supervisory personnel. Moreover, variations on turbine exhaust gas temperature or/and flow do not affect the functionality of the ORC plant.

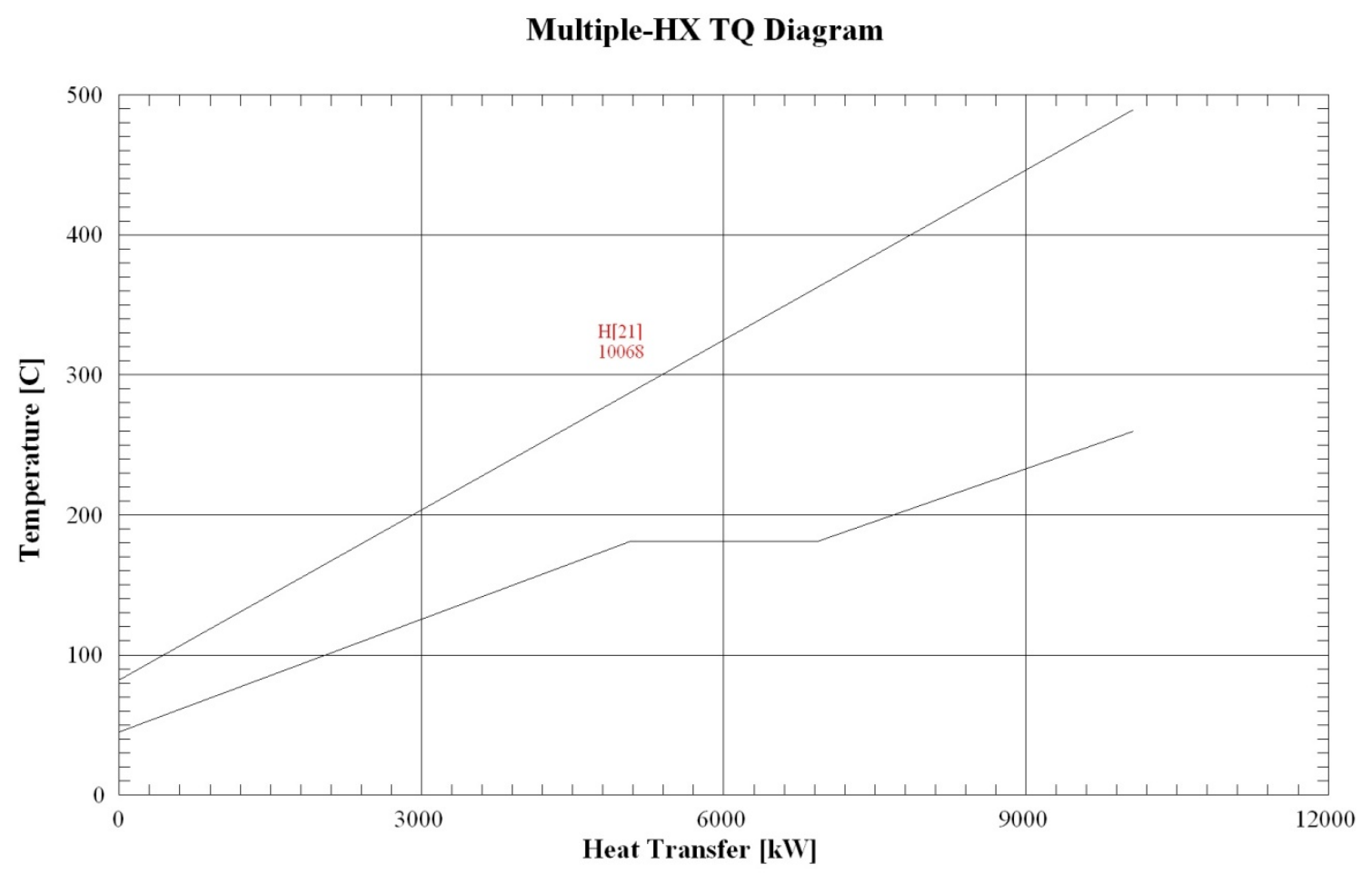

Figure 2. T-Q diagram of the heat recovery process in the heat exchanger

\section{WORKING FLUID SELECTION}

The selection of the working fluid is of key importance in ORCs. Due to the low temperature heat transfer inefficiencies are extremely prejudicial to the net efficiency of the cycle. These inefficiencies depend very strongly on the thermodynamic properties of the working fluid. The choice of proper working fluid has been discussed in some studies [7, 8, 9 and 10]. with findings which can be summarized as follow:

- Thermodynamic performance: The efficiency and/or output power should be as high as possible for the given heat source and heat sink temperatures. This generally involves low pump consumption and high critical point. 
- High specific heat of and density: A fluid which has a higher latent heat and density can absorb more energy from the exhaust gas of GT in the heat exchanger and consequently reduce the mass flow rate of the working fluid and the size of the plant.

- Low freezing point: The freezing point of the fluid must be lower than the lowest temperature of the ORC

- Low environmental impact and safety: The major parameters are the Ozone Depleting Potential (ODP), Greenhouse Warming Potential (GWP), the toxicity and the flammability.

- Low cost

The study focused on 10 working fluids; according to the mentioned criteria and the most appropriate working fluid is chosen n-Pentane for the simulations. Thermodynamic properties and the environmental data for $\mathrm{n}$-Pentane are given in Table 2.

Table 2. Thermodynamic properties and the environmental data for $n$-Pentane

\begin{tabular}{lc}
\hline \multicolumn{1}{c}{ Thermodynamic properties } & Value \\
\hline Critical point & $196\left[{ }^{\circ} \mathrm{C}\right]-33.6[$ bar $]$ \\
Vaporization heat at $1 \mathrm{~atm}$. & $358.7[\mathrm{~kJ} / \mathrm{kg}]$ \\
Boiling temperature & $35.5\left[{ }^{\circ} \mathrm{C}\right]$ \\
Safety & Flammable \\
\hline \multicolumn{1}{c}{ Environmental data } & Value \\
\hline ODP $\quad \sim 0$ \\
Net GWP 100 year & $\sim 20$ \\
ASHRAE level of safety & $\mathrm{A} 3$ \\
\hline
\end{tabular}

\section{ECONOMIC APPRAISAL OF THE PROJECT}

Economic appraisal models provide an objective framework for the assessment of the profits obtained from investments in utilization of the waste heat of the NGCS. In this study, simple payback method and the net present value method is employed in order to perform an economical appraisal model of the project.

The payback period method refers to the period of time required for the return on an investment to repay the sum of the original investment. Moreover, the time value of money is not taken into account. The general form of the formula of the payback period method is given in Equation 1. Equation 2 shows the application of the Equation 1 to the energy saving projects.

Payback period $(P B P)=\frac{\text { Total investment cost }}{\text { Annual benefit }}$

$P B P=\frac{\text { Total } \text { investment cost }}{\text { Annual saving with current energy prices }}$ 
The net present value method can be defined as the difference between the present values of the future cash flows from an investment and the amount of the investment. Present worth of the expected cash flows is computed by discounting them at the required rate of return. Quoilin and Lemort [10] expressed the net present worth as given in Equation 3.

$N P W=P W$ of benefits $-\mathrm{PW}$ of costs

In the calculation of net present value of benefits or costs Equation 4 can be used. Series present worth of benefits or costs can be evaluated by using Equation 5. If the NPW of benefits is higher than the costs the project is accepted.

$\operatorname{Pr}=F(1+i)^{-n}$

$$
\operatorname{Pr}=A\left[\frac{(1+i)^{n}-1}{i(1+i)^{n}}\right]
$$

\section{RESULTS}

An ORC power plant coupled to NGCS and the simulations performed by using THERMOFLEX software. The site conditions and the thermodynamic properties of the different streams of NGCS and ORC power plant, indicated in Fig. 1, were presented respectively in Table 3 and 4 . The following assumptions are considered during this study.

- The ambient temperature is considered to be $15^{\circ} \mathrm{C}$

- The minimum pinch temperature difference in the evaporator can be assumed to be $3^{\circ} \mathrm{C}$

- The isentropic efficiencies for the refrigerant turbine and pump are taken $85 \%$

- The specific investment cost of the ORC is $3610 \$ / \mathrm{kW}_{\mathrm{el}}$

- Equivalent electricity cost and inflation rate in Turkey are respectively $0.12 \$$ and $9 \%$

- Economic lifetime of plant is presumed as 25 years

- O\&M cost is assumed to be $1 \%$ of total investment cost

- Salvage value of the power plant is accepted $5 \%$ of primary investment cost

Table 3. Ambient conditions of the NGCS-ORC

\begin{tabular}{lc}
\hline Properties & Value \\
\hline Site altitude & $1185[\mathrm{~m}]$ \\
Ambient temperature & $15\left[{ }^{\circ} \mathrm{C}\right]$ \\
Ambient pressure & $0.88[\mathrm{bar}]$ \\
Ambient relative humidity & $57[\%]$ \\
Ambient wet bulb temperature & 10.56 \\
\hline
\end{tabular}


Table 4. Thermodynamic properties of each stream of the NGCS and ORC

\begin{tabular}{crcr}
\hline Point & $\mathrm{T}\left[{ }^{\circ} \mathrm{C}\right]$ & $\mathrm{P}[\mathrm{kPa}]$ & $\mathrm{m}[\mathrm{kg} / \mathrm{s}]$ \\
\hline 1 & 25.7 & 6100.00 & 77.51 \\
2 & 24.82 & 87.88 & 90.72 \\
3 & 7.70 & 4800.00 & 77.89 \\
4 & 476.20 & 89.64 & 24.13 \\
5 & 15.00 & 8788.00 & 23.75 \\
6 & 32.20 & 87.88 & 90.72 \\
7 & 33.87 & 7172.00 & 77.51 \\
8 & 26.81 & 7300.00 & 77.51 \\
9 & 15.00 & 8788.00 & 90.72 \\
10 & 15.00 & 87.88 & 90.72 \\
11 & 24.61 & 87.70 & 90.72 \\
12 & 20.00 & 59.76 & 77.51 \\
13 & 32.00 & 87.70 & 90.72 \\
14 & 23.94 & 7031.00 & 77.51 \\
15 & 7.70 & 4800.00 & 77.51 \\
16 & 7.70 & 1716.00 & 0.38 \\
17 & 39.20 & 120.00 & 12.88 \\
18 & 25.00 & 87.00 & 840.00 \\
19 & 15.00 & 87.00 & 840.00 \\
20 & 82.22 & 87.88 & 24.13 \\
21 & 260.00 & 2613.00 & 12.88 \\
22 & 42.75 & 27.70 & 12.88 \\
23 & 188.40 & 1200.00 & 12.88 \\
\hline
\end{tabular}

\subsection{TECHNICAL RESULTS}

Table 5 illustrates a summary of the energy results for generating electricity from ORC. Figure 3, shows the average daily ambient temperature changes for 2009 in Erzincan region and produced net power from the simulated ORC during the year [11]. Average temperature of the warmest and coldest day during a year is 24 and $-14^{\circ} \mathrm{C}$ respectively. Net power productions in these days are 1362.8 and $1474.5 \mathrm{~kW}$ respectively. By considering load factor of the ORC power plant as $90 \%$ (7884 hours per year), annual produced energy via the plant is calculated approximately $11,000,000 \mathrm{kWhr}$, which shows a high amount of energy saving from waste heat of compression station and consequently impressive reduction on its global warming impact. According to the experience of existing plants, ORC plants have the advantage of increasing the annual load operating hours up. Therefore, the function of the ORC power plant with different load factors is also computed and its connection with annual energy saving and payback time is presented in Figure 4. Increasing load factor means an increment in annual energy saving and reduction in payback time. 
Table 5. Summary of the results for NGCS-ORC

\begin{tabular}{ll}
\hline Properties & \multicolumn{1}{c}{ Value } \\
\hline Total shaft power of GT & $5452[\mathrm{~kW}]$ \\
Total shaft power of fuel compressions & $5452[\mathrm{~kW}]$ \\
Total output power of refrigerant & $1675[\mathrm{~kW}]$ \\
Total auxiliaries & $290[\mathrm{~kW}]$ \\
Net power & $1385[\mathrm{~kW}]$ \\
Total transferred heat in evaporator & $10202[\mathrm{~kW}]$ \\
\hline
\end{tabular}

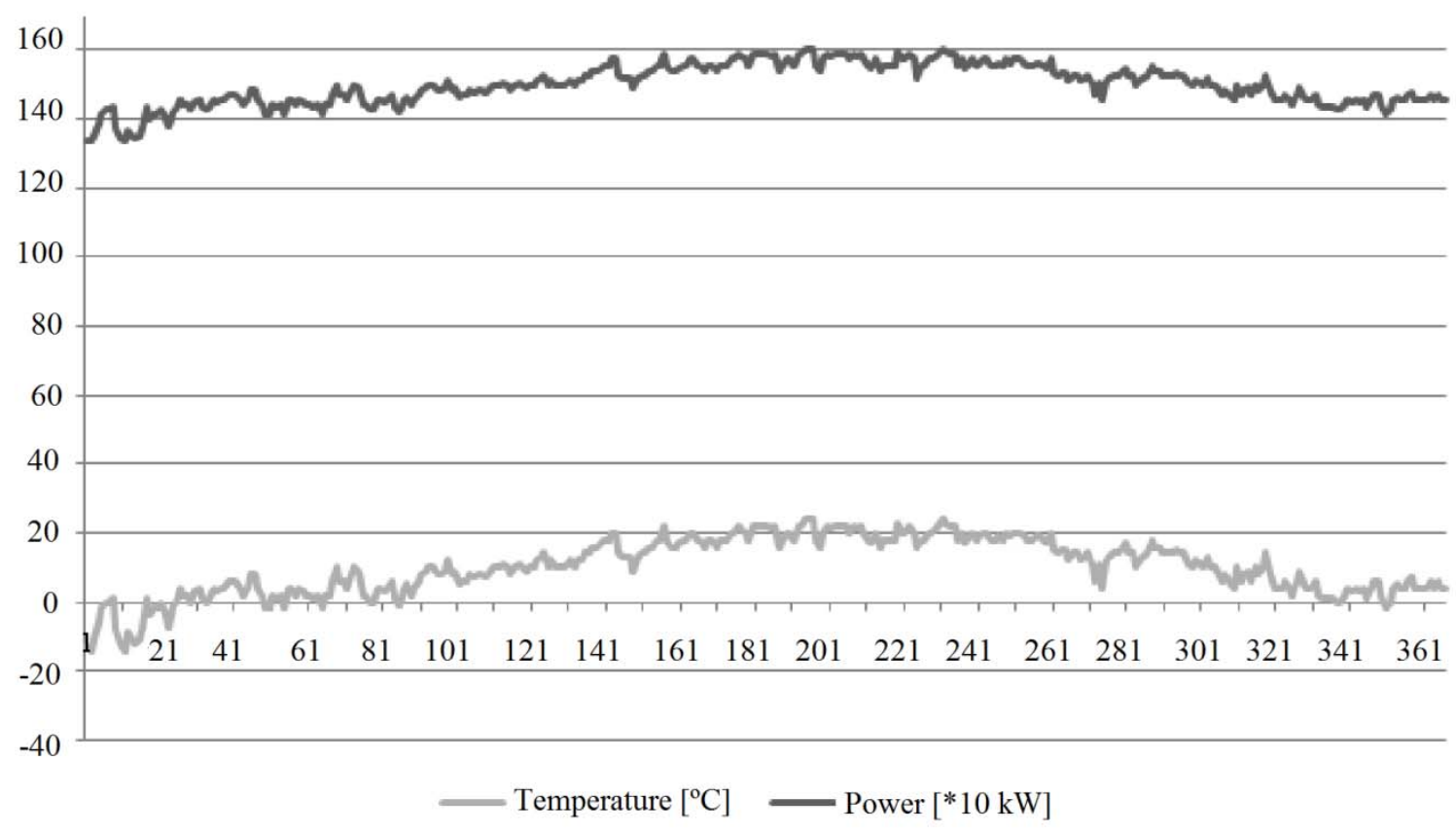

Figure 3. The ambient temperature variation and net power production during the year in the simulated ORC in Erzincan 


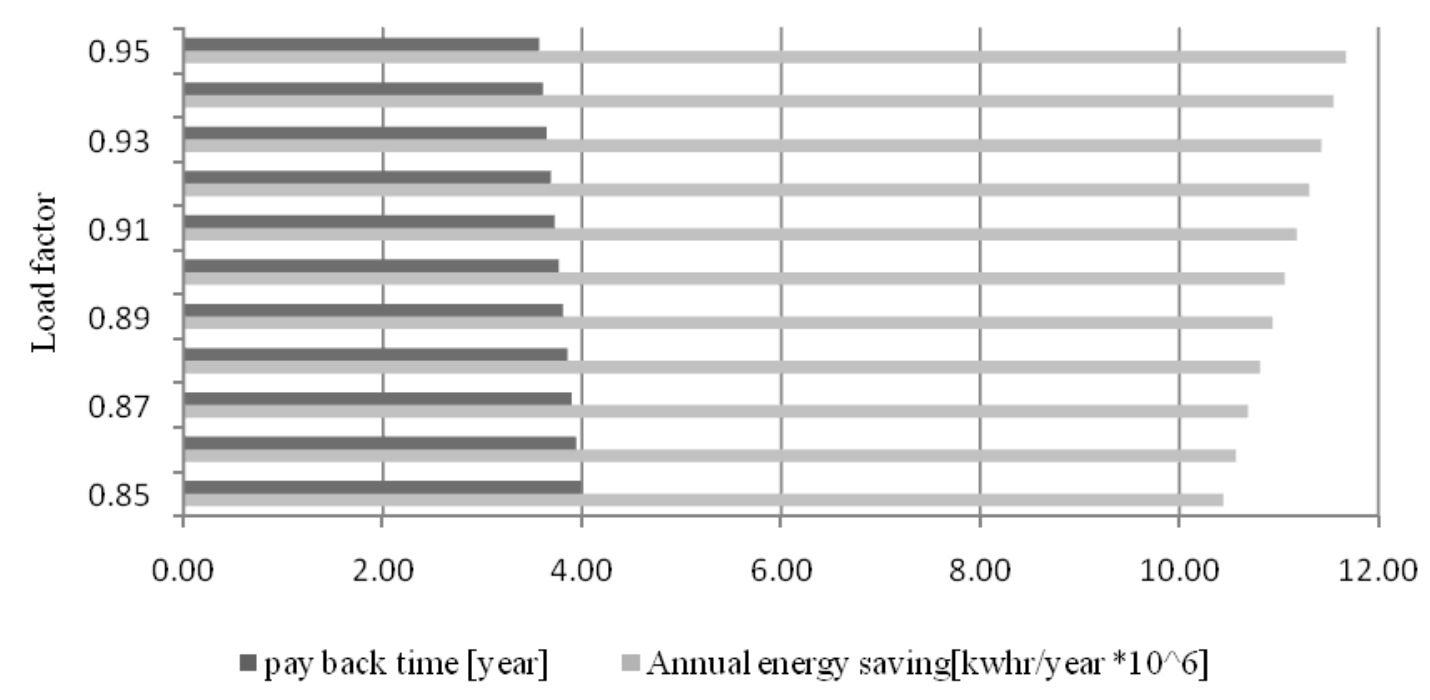

Fig.4.The relation between load factor and annual energy saving and payback time of the ORC power plant

\subsection{ECONOMICAL RESULTS}

The economical evaluation of the ORC power plant was applied using equations and assumptions in previous sections. The results are summarized in Table 6. It shows that, the return on investment occurs in first four years of the operation, which is another major benefit of the project. The present worth of the benefits and costs at the end of economical lifetime of project are 13,062,613.60 and 5,491,128.98 \$ respectively. By using Eq.3, NPW of the project is calculated 7,571,484.62 \$, which is positive and as it mentioned in previous section, the project is economically feasible. The discount rate is taken $9 \%$ in the economical analysis. 
Table 6. Cash flow and economic analysis result of the NGCS-ORC power plant

\begin{tabular}{|c|c|c|c|c|}
\hline Years & $\begin{array}{c}\text { Investment cost } \\
{[\$]}\end{array}$ & $\begin{array}{l}\text { Annual energy } \\
\text { saving [\$/Year] }\end{array}$ & O\&M [\$/Year $]$ & $\begin{array}{c}\text { Salvage value } \\
{[\$]}\end{array}$ \\
\hline 0 & $5,000,000.00$ & - & - & - \\
\hline 1 & - & $1,326,904.15$ & $50,000.00$ & - \\
\hline 2 & - & $1,326,904.15$ & $50,000.00$ & - \\
\hline 3 & - & $1,326,904.15$ & $50,000.00$ & - \\
\hline 4 & - & $1,326,904.15$ & $50,000.00$ & - \\
\hline 5 & - & $1,326,904.15$ & $50,000.00$ & - \\
\hline 6 & - & $1,326,904.15$ & $50,000.00$ & - \\
\hline 7 & - & $1,326,904.15$ & $50,000.00$ & - \\
\hline 8 & - & $1,326,904.15$ & $50,000.00$ & - \\
\hline 9 & - & $1,326,904.15$ & $50,000.00$ & - \\
\hline 10 & - & $1,326,904.15$ & $50,000.00$ & - \\
\hline 11 & - & $1,326,904.15$ & $50,000.00$ & - \\
\hline 12 & - & $1,326,904.15$ & $50,000.00$ & - \\
\hline 13 & - & $1,326,904.15$ & $50,000.00$ & - \\
\hline 14 & - & $1,326,904.15$ & $50,000.00$ & - \\
\hline 15 & - & $1,326,904.15$ & $50,000.00$ & - \\
\hline 16 & - & $1,326,904.15$ & $50,000.00$ & - \\
\hline 17 & - & $1,326,904.15$ & $50,000.00$ & - \\
\hline 18 & - & $1,326,904.15$ & $50,000.00$ & - \\
\hline 19 & - & $1,326,904.15$ & $50,000.00$ & - \\
\hline 20 & - & $1,326,904.15$ & $50,000.00$ & - \\
\hline 21 & - & $1,326,904.15$ & $50,000.00$ & - \\
\hline 22 & - & $1,326,904.15$ & $50,000.00$ & - \\
\hline 23 & - & $1,326,904.15$ & $50,000.00$ & - \\
\hline 24 & - & $1,326,904.15$ & $50,000.00$ & - \\
\hline \multirow[t]{3}{*}{25} & - & - & - & $250,000.00$ \\
\hline & $\begin{array}{c}\text { Payback time } \\
\text { [Year] }\end{array}$ & $\begin{array}{c}\text { PW of benefits } \\
{[\$]}\end{array}$ & $\mathrm{PW}$ of cost $[\$]$ & NPW [\$] \\
\hline & 3.77 & $13,062,613.60$ & $5,491,128.98$ & $7,571,484.62$ \\
\hline
\end{tabular}

\section{CONCLUSIONS}

In this study, a natural gas compression station and an Organic Rankine cycle is designed based on real data and then an economic analysis is performed for the decision of installing an ORC to the NGCS. Coupling ORC unit to a NGCS provides economical and enviromental solutions to significantly improve the efficiency and reduce the energy costs of gas transportation sector. Some important results from this study are summarized as below.

1. The waste heat of a NGCS can be utilized by an ORC to generate electricity.

2. n-Pentane is selected as working fluid of ORC from both thermodynamic efficiency and environmental aspects.

3. Annually energy saving by installation of an ORC unit to NGCS is $11,000,000 \mathrm{~kW}$ hr. 
4. The economic analysis performed in this study shows that the investment can return in 3.77 years. Moreover, the net present worth of the project is 7,571,500 \$, which means that project is acceptable and feasible.

\section{NOMENCLATURE}

$\begin{array}{lll}\text { A } & \text { An end-of-period cash receipt } & \\ \mathrm{F} & \text { A future sum of money } & \\ \mathrm{i} & \text { Interest rate per interest period } & \\ \mathrm{m} & \text { Mass flow rate } & {[\mathrm{kg} / \mathrm{s}]} \\ \mathrm{P} & \text { Pressure } & {[\mathrm{bar}]} \\ \mathrm{T} & \text { Temperature } & {\left[{ }^{\circ} \mathrm{C}\right]} \\ \mathrm{Pr} & \text { A present sum of money } & \\ \text { O\&M } & \text { Operation and Maintenance } & \end{array}$

\section{REFERENCES}

[1] Wei D., Lu X., Zhen Lu, Gu J., 2007, "Performance analysis and optimization of organic Rankine cycle (ORC) for waste heat recovery", Energy Conversion and Management, 48, 1113-1119

[2] Kurz R., Ohanian S., 2003, "Modeling Turbo machinery in Pipeline Simulations”, PSIG Annual Meeting, Bern, Switzerland.

[3] Schuster A., Karellas S., Kakaras E., Spliethoff H., 2009, "Energetic and economic investigation of Organic Rankine Cycle applications", Applied Thermal Engineering, 29, 1809-1817.

[4] Dai Y., 2009, Wang J., Gao L., "Parametric optimization and comparative study of organic Rankine cycle (ORC) for low grade waste heat recovery", Energy Conversion and Management, 50, 576-582.

[5] Hung T.C., 2001, "Waste heat recovery of organic Rankine cycle using dry fluids", Energy Conversion Management, 42, 539-551.

[6] Thermoflex, Thermoflow. Inc. 29 Hudson Road Sudbury. MA $01776 \cdot$ USA

[7] Karellas S., Schuster A., 2008, "Supercritical Fluid Parameters in Organic Rankine Cycle Applications", Int. J. of Thermodynamics ISSN 1301-9724, 11, 101-108.

[8] Saleh B., Koglbauer G., Wendland M., Fischer J., 2007, "Working fluids for lowtemperature Organic Rankine Cycles", Energy 32, 1210-1221.

[9] Borsukiewcz-Gozdur A., Nowak W., 2007, "Comparative analysis of natural and synthetic refrigerants in application to low temperature Clausius-Rankine cycle", Energy, 32, 344-352.

[10] Quoilin S., Lemort V., 2007, "Technological and Economical Survey of Organic Rankine Cycle Systems", $5^{\text {th }}$ European conference economics and management of energy industry, Portugal.

[11] Internet, http://www.wunderground.com, 2010.

[12] Newman D. G., Wheeler E., 2004, "Study Guide for Engineering Economic Analysis", Ninth edition, Oxford University press Inc. 